\title{
Definition and characteristics of acute exacerbation in adult patients with chronic rhinosinusitis: a systematic review
}

\author{
Dawei $\mathrm{Wu}^{1} \mathbb{B}$, Benjamin Bleier ${ }^{2^{*}}$ and Yongxiang $\mathrm{Wei}^{1^{*}}$
}

\begin{abstract}
Background: Acute exacerbations (AE) in chronic rhinosinusitis (CRS) have been increasingly recognized as an important clinical issue. The purpose of this study is to summarize the current definitions and evaluation parameters of AE and then identify and quantify the clinical and immunopathologic characteristics of AE in CRS.

Methods: A systematic review of the literature was performed on PubMed, Scopus, and Cochrane databases from January 1990 through August 2020 to identify studies relating to AE in CRS. Exclusion criteria included non-English and non-human studies, and case reports.

Results: The definitions of AE in CRS among all the studies were based on a description of short-term worsening sinonasal symptoms. Patient-reported sinus infection and exacerbation related medical treatment during the preceding 3 months to 1 year were used to evaluate the frequency of AE in CRS. The average decline in 22-item Sino-Nasal Outcome Test (SNOT-22) score during an exacerbation was 7.83 points relative to baseline. Comorbid asthma, SNOT-22 scores $\geq 24$, allergic rhinitis, eosinophil count $\geq 150 / \mu \mathrm{L}$ and autoimmune disease were positively associated with an exacerbation-prone CRS phenotype. AE in chronic rhinosinusitis with nasal polyps (CRSwNP) was associated with increased expression of mucus cytokines including myeloperoxidase (percentage increase $[\mathrm{PI}]=$ 101\%), IL-5 (PI = 125\%), and IL-6 (PI = 162\%) and could be predicted by the increasing mucus cystatin and periostin.

Conclusion: The definition of AE in CRS is largely driven by patient-reported symptoms and is associated with several risk factors. Quantitative changes in mucus cytokines associated with AE in CRSwNP and may be used to predict events. The development of a consistent definition of AE in CRS is critical to help define disease control and treatment efficacy.
\end{abstract}

Keywords: Chronic rhinosinusitis, Nasal polyps, Acute exacerbation, Definition, Clinical characteristics, Immunologic characteristics, Risk factors, Etiology

\footnotetext{
*Correspondence: benjamin_bleier@meei.harvard.edu; yongxw67@163.com

${ }^{2}$ Department of Otolaryngology, Massachusetts Eye and Ear Infirmary,

Harvard Medical School, 243 Charles Street, Boston, MA 02114, USA

${ }^{1}$ Department of Otolaryngology-Head and Neck Surgery, Beijing Anzhen

Hospital, Capital Medical University, Anzhen Road 2, Chaoyang District,

Beijing 100029, China
}

C C The Author(s). 2020 Open Access This article is licensed under a Creative Commons Attribution 4.0 International License, which permits use, sharing, adaptation, distribution and reproduction in any medium or format, as long as you give appropriate credit to the original author(s) and the source, provide a link to the Creative Commons licence, and indicate if changes were made. The images or other third party material in this article are included in the article's Creative Commons licence, unless indicated otherwise in a credit line to the material. If material is not included in the article's Creative Commons licence and your intended use is not permitted by statutory regulation or exceeds the permitted use, you will need to obtain permission directly from the copyright holder. To view a copy of this licence, visit http://creativecommons.org/licenses/by/4.0/ The Creative Commons Public Domain Dedication waiver (http://creativecommons.org/publicdomain/zero/1.0/) applies to the data made available in this article, unless otherwise stated in a credit line to the data. 


\section{Introduction}

Chronic rhinosinusitis (CRS) is often associated with a fluctuating disease course. Acute exacerbations (AE) in CRS have been shown to directly account for increasing healthcare costs $[1,2]$, annual physician visits [3], and significant decreases in workplace productivity $[4,5]$. Recently, the frequency of $\mathrm{AE}$ has been identified as an independent predictor of quality of life [6]. Based on the current guidelines, an acute exacerbation is defined as an acute and transient worsening of preexisting symptoms in patients with CRS $[7,8]$. However, there is no consensus definition of how to quantify AE due to multifactorial etiologies and inconsistency in endpoint reporting.

Prior attempts to report on AE have relied on empirical clinical criteria. For example, Rank et al. utilized diagnosis coding and at least one of the following: prescription for systemic antibiotics, systemic corticosteroids, plans for surgical intervention, emergency department or urgent care visit, or hospitalization for CRS [9]. Similarly, Sedaghat et al. used three metrics to assess the frequency of $\mathrm{AE}$ including patient-reported sinus infections, CRS-related antibiotic courses, and CRS-related oral corticosteroid courses, each over the preceding 3 months $[6,10,11]$. These direct treatmentrelated metrics of $\mathrm{AE}$ facilitate assessment on the $\mathrm{AE}$ in CRS but fail to correlate the AE in CRS with both degree of subjective changes in clinical symptoms and objective measures of inflammation.

The purpose of this study is to therefore utilize a systematic review of the literature to summarize the current definitions and evaluation parameters of $\mathrm{AE}$ and then quantify both the clinical and immunopathologic characteristics of AE in patients with CRS.

\section{Methods}

An evidence-based systematic review was performed utilizing the Preferred Reporting Items for Systematic Reviews and Meta-Analysis (PRISMA) guidelines. A comprehensive search of PubMed, Scopus, and Cochrane databases from January 1990 through August 2020 was conducted to identify studies relating to the $\mathrm{AE}$ in CRS. A combination of terms was used to maximize the probability of finding all relevant publications: acute exacerbation, exacerbation, chronic rhinosinusitis, rhinosinusitis, chronic sinusitis, nasal polyps and polyposis.

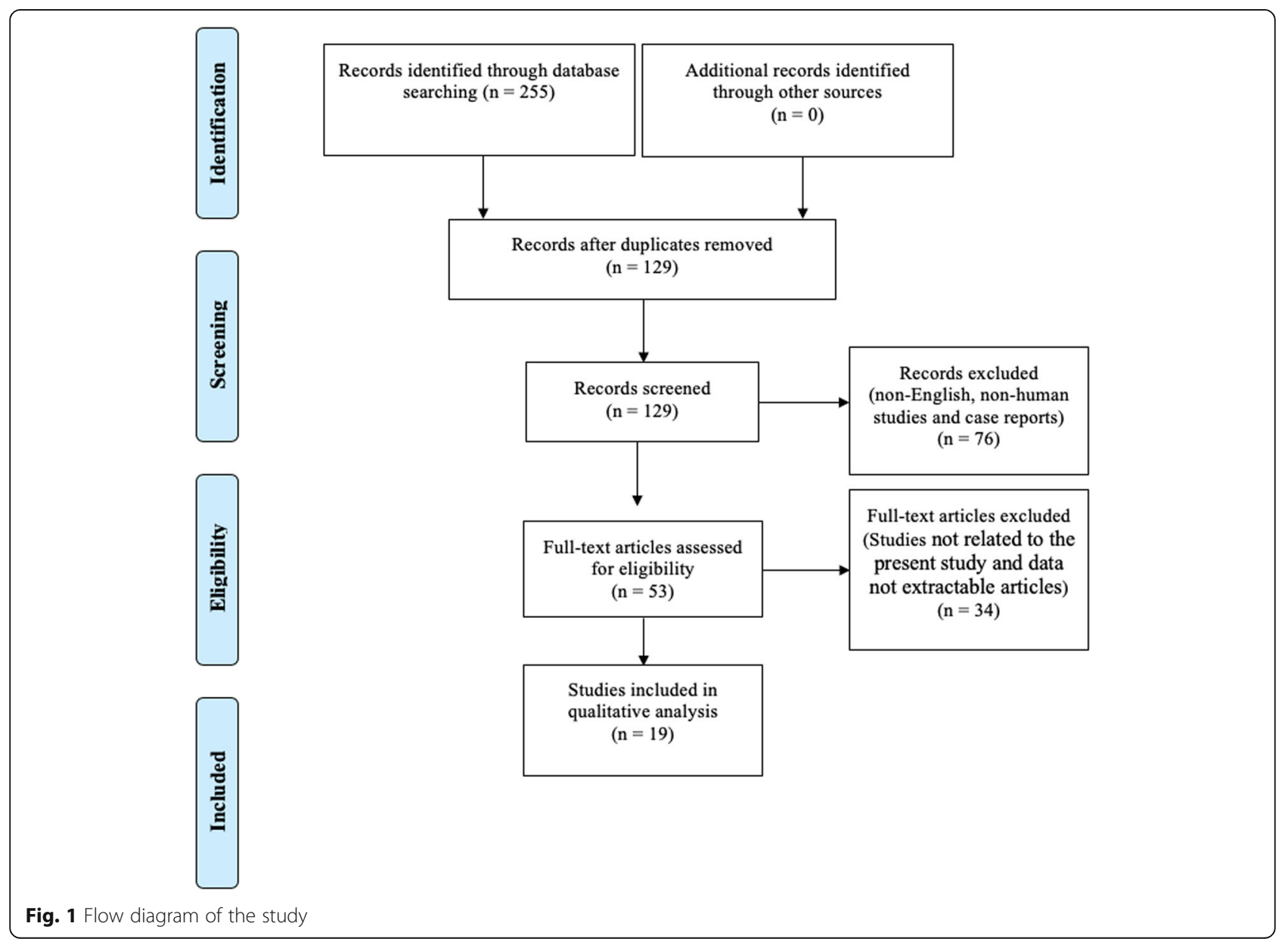




\section{Study selection}

Titles and abstracts of all the relevant studies were reviewed by 2 independent authors (DW and YW). Included studies addressed the etiology, characteristics, and diagnosis of AE in CRS. All included studies were downloaded and the full-text was reviewed by both authors. Studies were excluded if they were: non-English, non-human studies, case reports, or not related to the present study. Figure 1 outlines the search strategy and inclusion process used to find relevant studies.

\section{Data extraction and analysis}

Data included year of publication, study design, age range, diagnostic criteria, bacterial findings, immunohistologic findings, risk factors, and conclusions. After analysis of each article, summary tables were developed. The quality of included studies was determined from the Oxford Center for Evidence Based Medicine Levels of Evidence categorization, based on study design as well as clinical endpoints [12].

\section{Results}

\section{Included studies}

The initial database search identified 255 articles (Fig. 1). Duplicates, non-full text, non-English, and data not extractable articles were excluded $(n=239)$. A total of 19 articles underwent a full-text assessment for eligibility and met the final inclusion criteria for systematic review. Nine studies explored the clinical characteristics of $\mathrm{AE}$ in CRS including the clinical metrics and risk factors of $\mathrm{AE}$ in CRS. Another seven articles focused on the in vivo immunologic characteristics associated with $\mathrm{AE}$ in CRSwNP.

\section{Diagnosis of AE in adult patients with CRS}

Diagnostic criteria regarding the presence of AE in CRS were summarized (Table 1). The definitions of $\mathrm{AE}$ in
CRS among all the studies were based on subjective descriptive changes in sinonasal symptoms. These included a sudden worsening of CRS symptoms with a return to baseline symptoms following treatment. Medical treatments during AE in CRS included short-term administration of antibiotics and corticosteroids.

\section{Quantitative clinical metrics of AE in CRS}

The evaluation parameters of AE in CRS in seven studies were summarized (Table 2 and Fig. 2). Number of sinus infections, CRS-related antibiotic use, and CRS-related oral corticosteroid use over prior time period were utilized in five studies to evaluate the frequency of $\mathrm{AE}$ in CRS $[6,11,18-20]$. The average number of reported sinus infections, CRS-related antibiotics, and CRSrelated oral corticosteroids per year were $3.53 \pm 1.30$, $2.44 \pm 1.42$, and $1.63 \pm 1.13$; respectively (Fig. 2a). Seven studies reported scores of the 22-item Sino- Nasal Outcome Test (SNOT-22) during active or inactive exacerbation in patients with CRS $[6,11,13,14,18-20]$. An average SNOT-22 score of $37.55 \pm 21.06$ was calculated during inactive exacerbation of CRS from six studies $[6$, $11,14,18-20]$. Only two studies reported the changes in SNOT-22 score during AE in CRS [13, 14]. The average change of SNOT-22 scores during an exacerbation was 7.83 points higher as compared with routine visits.

\section{Clinical risk factors for AE in CRS}

We further summarized the clinical risk factors for the AE in CRS (Table 3 and Fig. 2b). Phillips et al. defined an exacerbation-prone CRS phenotype among patients who reported over 3 exacerbations in the preceding 12 months [18]. Comorbid asthma (adjusted OR $=3.68$ ), elevated SNOT-22 scores (adjusted OR $=1.06$ ) and nasal polyps (adjusted $\mathrm{OR}=0.27$ ) were significantly associated with an exacerbation-prone CRS phenotype (Fig. 2b).

Table 1 Descriptive diagnosis of acute exacerbations in adult patients with CRS

\begin{tabular}{|c|c|}
\hline Author/year & Definition of an acute exacerbation in CRS \\
\hline $\begin{array}{l}\text { Zemke, et al. (2019) } \\
\text { [13] }\end{array}$ & $\begin{array}{l}\text { The presence of increased nasal congestion, and facial pain; increased sinonasal discharge; usually presence of an } \\
\text { unscheduled sick visit. }\end{array}$ \\
\hline $\begin{array}{l}\text { Orlandi, RR, et al. } \\
\text { (2018) [8] }\end{array}$ & $\begin{array}{l}\text { AE in CRS is defined in a patient in whom a previous diagnosis of CRS exists, and a sudden worsening of symptoms occurs, } \\
\text { with a return to baseline symptoms following treatment. }\end{array}$ \\
\hline $\begin{array}{l}\text { Divekar, et al. (2015) } \\
\text { [14] }\end{array}$ & $\begin{array}{l}\text { A natural exacerbation was defined as patient-reported worsening of sinonasal symptoms (i.e. runny nose, nasal congestion, } \\
\text { and nasal obstruction). }\end{array}$ \\
\hline $\begin{array}{l}\text { Fokkens, et al. (2012) } \\
\text { [7] }\end{array}$ & $\begin{array}{l}\text { A history of sudden worsening of preexisting symptoms suggests an acute exacerbation of chronic rhinosinusitis, which } \\
\text { should be diagnosed by similar criteria and treated in a similar way to ARS. }\end{array}$ \\
\hline $\begin{array}{l}\text { Kuiper, et al. (2018) } \\
\text { [15] }\end{array}$ & $\begin{array}{l}\text { Self-reported medication use (antibiotics and oral corticosteroids) for worsened nasal and sinus symptoms; self-reported } \\
\text { worsened purulence in the past } 4 \text { weeks. }\end{array}$ \\
\hline Rank, et al. (2010) [16] & $\begin{array}{l}\text { Systemic antibiotics; systemic corticosteroid; plans for a semi-urgent surgical intervention; emergency department or urgent } \\
\text { care visit, or a hospitalization for CRS. }\end{array}$ \\
\hline Reh, et al. (2009) [17] & Worse nasal symptoms \\
\hline
\end{tabular}

CRS Chronic rhinosinusitis, CF Cystic fibrosis, AE Acute exacerbation, ICAR: RS International Consensus Statement on Allergy and Rhinology: Rhinosinusitis, EPOS European position paper on rhinosinusitis and nasal polyps, ARS Acute rhinosinusitis 
Table 2 Quantifiable metrics of acute exacerbations in CRS

\begin{tabular}{|c|c|c|c|c|}
\hline $\begin{array}{l}\text { Author/ } \\
\text { year }\end{array}$ & Evaluation parameters of $\mathrm{AE}$ & Results & Conclusions & $\begin{array}{l}\text { Level of } \\
\text { evidence }\end{array}$ \\
\hline $\begin{array}{l}\text { Phillips, } \\
\text { et al. } \\
\text { (2017) [6] }\end{array}$ & $\begin{array}{l}\text { Number of CRS-related anti- } \\
\text { biotics usage, sinus } \\
\text { infections }\end{array}$ & $\begin{array}{l}\text { SNOT- } 22 \text { score is associated with the number } \\
\text { of antibiotics; Antibiotic usage highly } \\
\text { correlated with the number of reported sinus } \\
\text { infections. }\end{array}$ & $\begin{array}{l}\text { Sinusitis-related antibiotic usage, reflecting the } \\
\text { frequency of acute CRS exacerbations, } \\
\text { mediates the association between CRS } \\
\text { symptomatology and QOL. }\end{array}$ & $3 a$ \\
\hline $\begin{array}{l}\text { Banoub, } \\
\text { et al. } \\
\text { (2018) [11] }\end{array}$ & $\begin{array}{l}\text { Number of sinus infections, } \\
\text { CRS-related antibiotics use, } \\
\text { CRS-related oral corticoste- } \\
\text { roids use }\end{array}$ & $\begin{array}{l}\text { The frequency of patient-reported sinus infec- } \\
\text { tions, CRS-related antibiotics courses and CRS- } \\
\text { related oral corticosteroid courses was nega- } \\
\text { tively associated with asthma control. }\end{array}$ & $\begin{array}{l}\text { AE are negatively associated with the level of } \\
\text { asthma control. }\end{array}$ & $3 a$ \\
\hline $\begin{array}{l}\text { Phillips, } \\
\text { et al. } \\
\text { (2019) [18] }\end{array}$ & $\begin{array}{l}\text { Number of sinus infections, } \\
\text { CRS-related antibiotics, CRS- } \\
\text { related oral corticosteroids }\end{array}$ & $\begin{array}{l}\text { AE positively associated with comorbid } \\
\text { asthma, and SNOT-22. }\end{array}$ & $\begin{array}{l}\text { A CRS exacerbation-prone phenotype charac- } \\
\text { terized by high sinonasal disease burden with } \\
\text { comorbid asthma. }\end{array}$ & $3 a$ \\
\hline $\begin{array}{l}\text { Sedaghat, } \\
\text { et al. } \\
\text { (2018) [19] }\end{array}$ & $\begin{array}{l}\text { Number of sinus infections, } \\
\text { CRS-related oral antibiotic, } \\
\text { CRS-related oral } \\
\text { corticosteroids }\end{array}$ & $\begin{array}{l}\text { At least } 1 \text { course of antibiotics or oral } \\
\text { corticosteroids in the last } 3 \text { months was the } \\
\text { optimal threshold for detecting poorly } \\
\text { controlled CRS. }\end{array}$ & $\begin{array}{l}\text { Number of CRS-related antibiotic use, and } \\
\text { CRS-related oral corticosteroid aid in the deter- } \\
\text { mination of global CRS control. }\end{array}$ & $3 a$ \\
\hline $\begin{array}{l}\text { Speth, } \\
\text { et al. } \\
\text { (2018) [20] }\end{array}$ & $\begin{array}{l}\text { Number of sinus infections, } \\
\text { CRS-related antibiotics, CRS- } \\
\text { related steroid usage }\end{array}$ & $\begin{array}{l}\text { SNOT- } 22 \text { score } \geq 30 \text { predicted at least } 1 \text { sinus } \\
\text { infection, CRS-related antibiotics, or CRS- } \\
\text { related oral corticosteroids in the past } 3 \\
\text { months. }\end{array}$ & $\begin{array}{l}\text { SNOT- } 22 \text { score and AE were predictive of each } \\
\text { other. }\end{array}$ & $3 a$ \\
\hline $\begin{array}{l}\text { Zemke, } \\
\text { et al. } \\
\text { (2019) [13] }\end{array}$ & SNOT-22 scores & $\begin{array}{l}\text { SNOT- } 22 \text { scores were } 4.9 \text { points higher during } \\
\text { the AE }\end{array}$ & Changes of SNOT-22 indicate the AE. & $3 a$ \\
\hline $\begin{array}{l}\text { Diveka, } \\
\text { et al. } \\
\text { (2015) [14] }\end{array}$ & SNOT-22 scores & $\begin{array}{l}\text { SNOT-22 scores were } 10.75 \text { higher during the } \\
\text { AE }\end{array}$ & Changes of SNOT-22 indicate the AE. & $3 a$ \\
\hline
\end{tabular}

CRS Chronic rhinosinusitis, AE Acute exacerbation, QOL Quality of life, SNOT-22 The 22-item Sino- Nasal Outcome Test
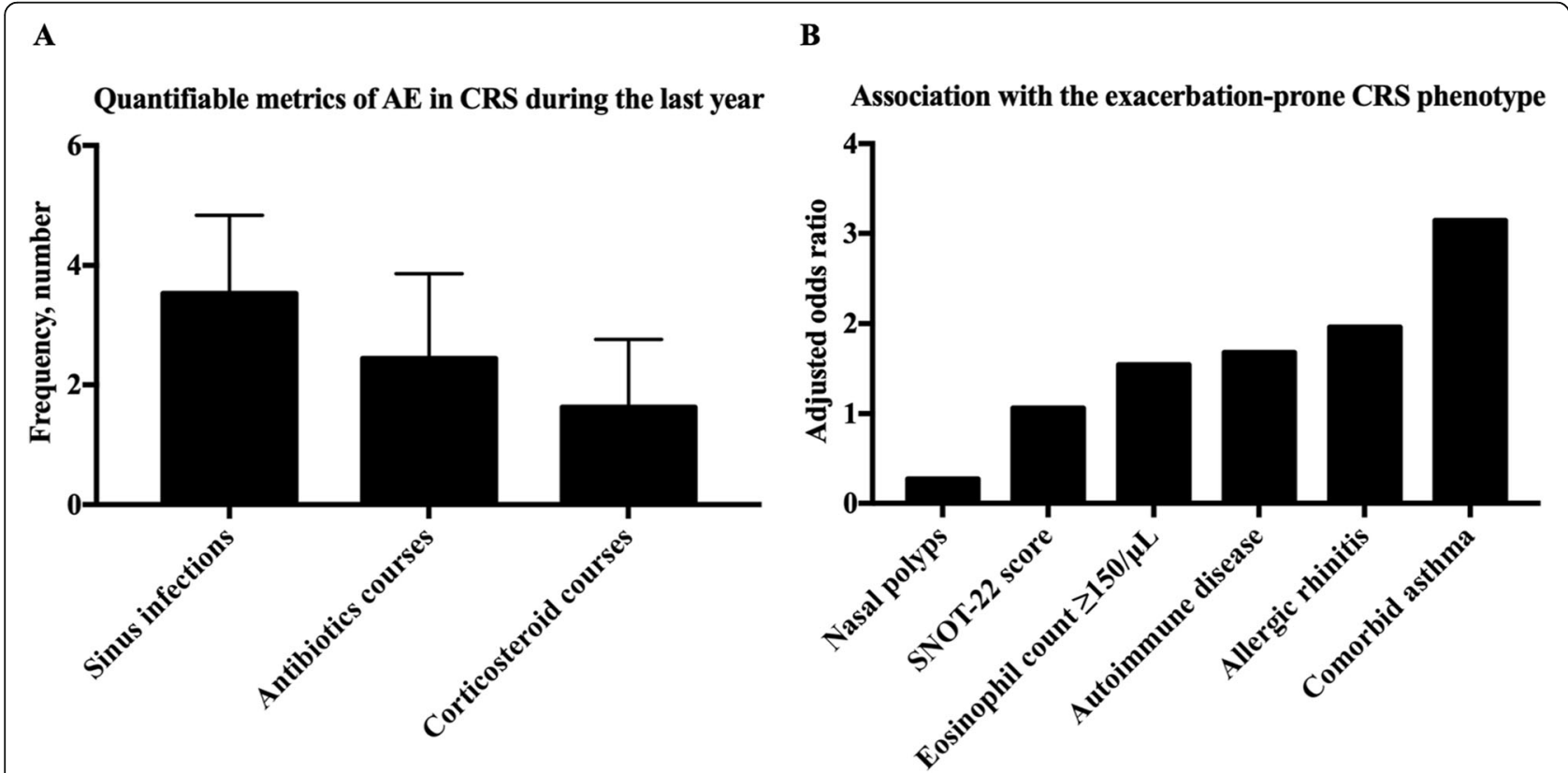

Fig. 2 Clinical characteristics of acute exacerbations in adult patients with CRS. a, quantifiable metrics of AE during the last year. b, association with the exacerbation-prone CRS phenotype. AE, acute exacerbation; SNOT-22, 22-itemSino-Nasal Outcome Test 
Table 3 Clinical risk factors for acute exacerbations in CRS

\begin{tabular}{|c|c|c|c|c|c|c|}
\hline Author/year & Study design & $\begin{array}{l}\text { Study } \\
\text { participants }\end{array}$ & $\begin{array}{l}\text { Definition of an acute } \\
\text { exacerbation }\end{array}$ & Clinical risk factors & Results & $\begin{array}{l}\text { Level of } \\
\text { evidence }\end{array}$ \\
\hline Rank, et al. (2010) [9] & $\begin{array}{l}\text { Retrospective } \\
\text { cohort study }\end{array}$ & $\begin{array}{l}\text { CRS } \\
\text { exacerbation }\end{array}$ & $\begin{array}{l}\text { Systemic antibiotics, } \\
\text { systemic corticosteroid, } \\
\text { plans for a semi-urgent sur- } \\
\text { gical intervention, emer- } \\
\text { gency department or urgent } \\
\text { care visit, or a hospitalization } \\
\text { for CRS. }\end{array}$ & Winter months & $\begin{array}{l}\text { Twice as likely to present } \\
\text { for a CRS exacerbation in } \\
\text { winter months compared } \\
\text { with spring, summer, or fall. }\end{array}$ & 4 \\
\hline $\begin{array}{l}\text { Banoub, et al. (2018) } \\
\text { [11] }\end{array}$ & Prospective & $\begin{array}{l}\text { Asthmatic } \\
\text { CRS }\end{array}$ & $\begin{array}{l}\text { Sinus infections, CRS-related } \\
\text { antibiotics use, CRS-related } \\
\text { oral corticosteroids use. }\end{array}$ & $\begin{array}{l}\text { Lower ACT scores } \\
\text { (Poor asthma } \\
\text { control). }\end{array}$ & $\begin{array}{l}\text { AE are negatively associated } \\
\text { with the level of asthma } \\
\text { control in asthmatic CRS } \\
\text { patients, independent of } \\
\text { CRS symptom severity. }\end{array}$ & 4 \\
\hline $\begin{array}{l}\text { Kuiper, et al. (2018) } \\
\text { [15] }\end{array}$ & Prospective & $\begin{array}{l}\text { Acute } \\
\text { exacerbations } \\
\text { of NSS in } \\
\text { patients with } \\
\text { CRS }\end{array}$ & $\begin{array}{l}\text { 1.Self-reported medication } \\
\text { use (antibiotics and oral } \\
\text { corticosteroids) for } \\
\text { worsened NSS; } 2 \text {. duration } \\
\text { ( } \geq 1 \text { week) of worsened } \\
\text { aggregate NSS; } 3 \text {. duration } \\
(\geq 1 \text { week) of worsened } \\
\text { aggregate NSS and self- } \\
\text { reported worsened puru- } \\
\text { lence in the past } 4 \text { weeks. }\end{array}$ & $\begin{array}{l}\text { Current long-term } \\
\text { CRS status, high body } \\
\text { mass index, asthma, } \\
\text { hay fever, sinus sur- } \\
\text { gery history, and win- } \\
\text { ter season. }\end{array}$ & $\begin{array}{l}\text { CRS status (current long- } \\
\text { term, current recent, past, } \\
\text { never), body mass index, } \\
\text { asthma, hay fever, sinus sur- } \\
\text { gery history, and winter sea- } \\
\text { son consistently predicted } \\
\text { acute exacerbations of NSS. }\end{array}$ & 4 \\
\hline Ikeda, et al. (2011) [21] & Prospective & $\begin{array}{l}\text { CRSwNP with } \\
\text { asthma } \\
\text { undergoing } \\
\text { ESS }\end{array}$ & $\begin{array}{l}\text { Acute exacerbation of CRS } \\
\text { defined by the presence of } \\
\text { purulent sinonasal } \\
\text { secretions in conjunction } \\
\text { with sinus-related } \\
\text { symptoms. }\end{array}$ & Bacterial infection & $\begin{array}{l}\text { Positive culture was } \\
\text { obtained in } 10 \text { out of } 11 \\
\text { patients. }\end{array}$ & 4 \\
\hline Kwah, et al. (2020) [22] & $\begin{array}{l}\text { Retrospective } \\
\text { cohort study }\end{array}$ & $\begin{array}{l}\text { frequent } \\
\text { exacerbations } \\
\text { of CRS }\end{array}$ & $\begin{array}{l}\text { worsening sinus symptoms } \\
\text { and CRS-related antibiotics } \\
\text { usage }\end{array}$ & $\begin{array}{l}\text { Asthma, allergic } \\
\text { rhinitis, eosinophil } \\
\text { count } \geq 150 / \mu \mathrm{L} \text {, and } \\
\text { autoimmune disease }\end{array}$ & $\begin{array}{l}\text { Frequent AECRS was } \\
\text { characterized by a higher } \\
\text { prevalence of asthma, } \\
\text { allergic rhinitis, eosinophil } \\
\text { count } \geq 150 / \mu \mathrm{L} \text {, } \\
\text { autoimmune disease. }\end{array}$ & 4 \\
\hline $\begin{array}{l}\text { Phillips, et al. (2018) } \\
\text { [23] }\end{array}$ & Prospective & $\begin{array}{l}\text { CRS } \\
\text { exacerbation }\end{array}$ & $\begin{array}{l}\text { CRS-related antibiotics } \\
\text { usage, sinus infections. }\end{array}$ & High SNOT-22 scores. & $\begin{array}{l}\text { SNOT-22 score is associated } \\
\text { with the number of } \\
\text { antibiotics which were } \\
\text { highly correlated with the } \\
\text { number of reported sinus } \\
\text { infections. }\end{array}$ & 4 \\
\hline
\end{tabular}

CRSwNP Chronic rhinosinusitis with nasal polyps, CRS Chronic rhinosinusitis, NSS Nasal and sinus symptoms, SNOT-22 The 22-item Sino- Nasal Outcome Test, ACT Asthma control test, AE Acute exacerbation, ESS Endoscopic sinus surgery

Furthermore, the SNOT-22 scores and AE of CRS were predictive of one other [20]. Rank et al. found that AE of CRS occurred in a distinct seasonal pattern where exacerbations were twice as likely to occur during winter months as compared with spring, summer, or fall [9]. Furthermore, Kuiper et al. found that body mass index, asthma, hay fever, sinus surgery history, and winter season consistently predicted acute exacerbations of nasal and sinus symptoms [15]. With respect to risk factor interactions, elevated baseline SNOT-22 were significantly and positively associated with antibiotic use in the past year [6]. Furthermore, asthma, the level of asthma control measured by Asthma Control Test (ACT) was negatively associated with the frequency of $\mathrm{AE}$ in CRS in the last 3 months, independent of CRS symptom severity [11]. For CRSwNP patients with asthma at the time of acute infectious episodes, positive bacterial cultures were obtained in $90.9 \%$ (10 out of 11) patients [21]. Kwah, et al. defined frequent exacerbations of CRS phenotype among patients who reported over 4 episodes over a 12month period in which an antibiotic was prescribed for worsening sinus symptoms [22]. The authors found that frequent exacerbations of CRS were associated with comorbid asthma (adjusted $\mathrm{OR}=2.61$ ), allergic rhinitis (adjusted $\mathrm{OR}=1.96$ ), eosinophil count $\geq 150 / \mu \mathrm{L}$ (adjusted $\mathrm{OR}=1.54$ ), and autoimmune disease (adjusted $\mathrm{OR}=$ 1.68).

\section{In vivo immunologic characteristics of $A E$ in $C R S$}

Immunologic characteristics of AE in CRSwNP in seven studies were summarized (Table 4 and Fig. 3). Local and systemic immune responses during $\mathrm{AE}$ in CRSwNP have 
Table 4 Immunologic characteristics of acute exacerbations in CRSwNP

\begin{tabular}{llll}
\hline Author/year & Study groups & Immunologic characteristics & Level of evidence \\
\hline Divekar, et al. (2015) [14] & CRSWNP $(n=9)$ & $\begin{array}{l}\text { Significant increase of nasal IL-5、IL-6 and eosinophil major basic protein. } \\
\text { Significant increase of serum VEGF and GM-CSF. }\end{array}$ & 4 \\
Rank, et al. (2013) [16] & CRSWNP $(n=10)$ & Significant increase of nasal IL-6, MBP, MPO, EDN and uric acid. & 4 \\
Mueller, et al. (2019) [24] & CRSWNP $(n=5)$ & Significant higher level of CST2 and periostin. & 4 \\
Ninomiya et al. (2018) [25] & ECRSWNP $(n=6)$ & Significant higher level of serum periostin. & 4 \\
Xu, et al. (2017) [26] & ECRSWNP $(n=30)$ & Significant higher level of serum periostin. & 2C \\
Kato, et al. (2018) [27] & ECRSWNP $(n=51)$ & Significant higher level of CST1. & 2C \\
Yan, et al. (2019) [28] & ECRSWNP $(n=192)$ & Significant higher level of serum periostin. & 2C \\
\hline
\end{tabular}

CRSWNP Chronic rhinosinusitis with nasal polyps, ECRSWNP Eosinophilic chronic rhinosinusitis with nasal polyps, VEGF Vascular endothelial growth factor, GM-CSF Granulocyte-macrophage colony-stimulating, MBP Major basic protein, MPO Myeloperoxidase, VEGF Vascular endothelial growth factor, EDN Eosinophil-derived neurotoxin, CST2 cystatin SA, CST1 Cystatin SN

been explored in two studies (Fig. 3) [14, 16]. Serum increases of 24 and $61 \%$ were observed in granulocytemacrophage colony-stimulating factor (GM-CSF) and vascular endothelial growth factor (VEGF), respectively. With respect to nasal secretions, eosinophilderived neurotoxin (EDN), myeloperoxidase (MPO), IL-5, IL-6, major basic protein (MBP), and uric acid (UA) were increased 64, 101, 125, 162, 209, and $217 \%$, respectively. Five studies explored the biomarkers of AE in CRSwNP. A significant increase of mucus cystatin SA (CST2) and periostin (PST) was observed in patients with recurrent CRSwNP as compared with stable CRSwNP after surgery within the 2- year follow-up [24]. The percentage increase of mucus PST and CST2 were 9.69 and 246.42\%, respectively. Another study by Ninomiya et al. showed that serum periostin higher than $115.5 \mathrm{ng} / \mathrm{ml}$ can predict the recurrence of CRSwNP [25]. Furthermore, significant expression of PST was highly associated with an eosinophilic CRSwNP [26], which is an intractable phenotype of CRSwNP. A study by Kato et al. also showed that significant higher level of Cystatin SN (CST1) mRNA in eosinophilc CRSwNP as compared with non-eosinophilc CRSwNP with a percentage increase of $983.33 \%$ [27], which was consistent with another study [28].

\section{Immunologic characteristics of AE in patients with CRSwNP}

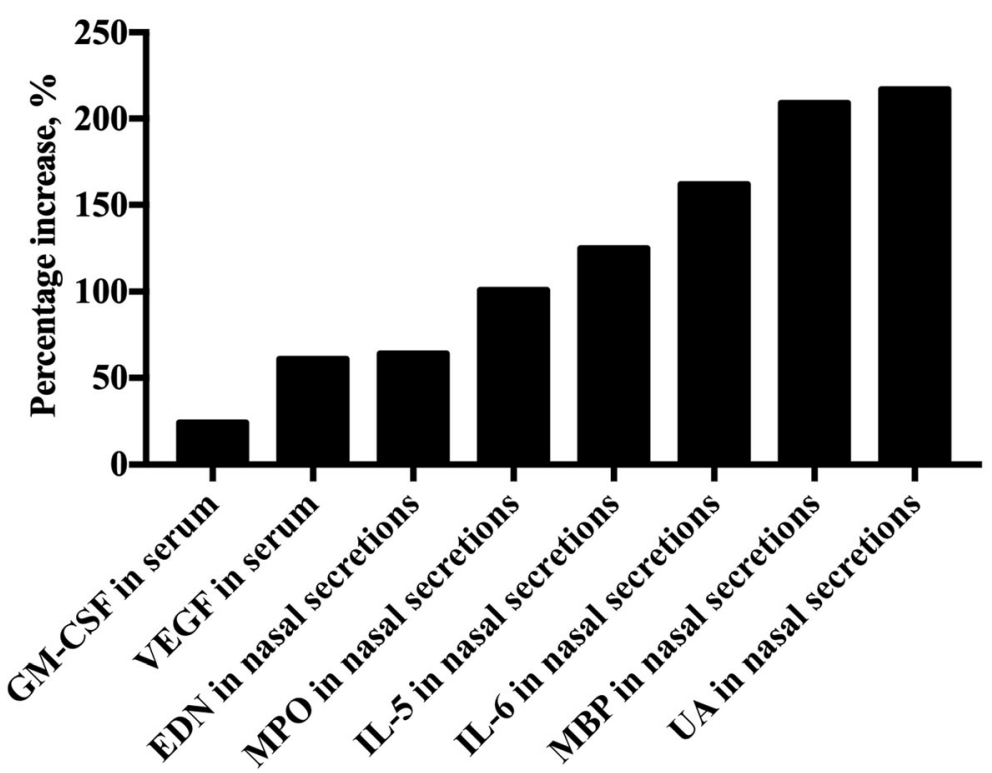

Fig. 3 Immunologic characteristics of acute exacerbations in adult patients with CRS. AE, acute exacerbations; CRSwNP, chronic rhinosinusitis with nasal polyps; GM-CSF, granulocyte-macrophage colony-stimulating; VEGF, vascular endothelial growth factor; EDN, eosinophil-derived neurotoxin; MPO, myeloperoxidase; MBP, major basic protein; UA, uric acid 


\section{Discussion}

Defining acute exacerbations of CRS with quantifiable clinical and immunologic metrics has remained a challenge due to the complex etiology of acute exacerbation and the inconsistency in endpoint reporting. Current guidelines regarding treatment of $\mathrm{AE}$ in CRS continue to recommend blanket medical intervention including short-course antibiotic treatment [7, 8]. Thus, an improved method of clinically defining AE in CRS and its risk factors is critical to facilitate individualized treatment as well as more effective preventions aimed improving overall quality of life.

We first reviewed the current diagnostic criteria of $\mathrm{AE}$ in CRS and found certain discrepancies between studies. The definitions of AE in CRS rely largely on descriptive changes in sinonasal symptoms that occurred in an acute fluctuation pattern (Table 1) [7, 8, 13-15, 17, 29]. Consequently, we sought to identify more specific quantitative metrics which could be used to provide a common definition between studies. Patient-reported number of sinus infections and treatments-related metrics were available in several studies (Fig. 1) [6, 9, 10]. An exacerbation-prone CRS phenotype was defined as more than 3 times of exacerbations in the last 12 months [18]. Previous studies showed that asthma, elevated SNOT-22 scores, allergic rhinitis, eosinophil count of at least 150 cells per microliter, and autoimmune disease were positively associated with an exacerbation-prone CRS phenotype $[18,22]$. However, the presence of nasal polyps was negatively associated an exacerbation-prone CRS phenotype [18]. This is similar to a previous study that found that CRSwNP are less likely to use antibiotics, which could serve as a proxy for an exacerbation, relative to other phenotypes of CRS patients [30]. SNOT-22 scores during active and inactive exacerbation were also characterized. A high average of SNOT-22 scores of $37.55 \pm$ 21.06 was calculated from six studies indicating a high subjective burden of disease among exacerbation prone patients $[6,11,14,18-20]$. In addition, average change in SNOT-22 score during an exacerbation was 7.83 points higher as compared with routine visits [13, 14]. The established minimal clinically important difference (MCID) for SNOT-22 is 9 to 12 based on two previous studies [23, 31]. While the SNOT22 change during exacerbation appears slightly below this accepted MCID, this may be due to smaller sample size or the fact that the MCID was validated against therapeutic interventions, not spontaneous exacerbations of chronic disease.

We next summarized the clinical risk factors for AE in CRS. Winter season, hay fever, asthma, sinus surgery history, current long-term CRS status, and high body mass index were all independent risk factors which predicted AE in CRS [9, 15]. Furthermore, high baseline SNOT-22 scores and low ACT scores were highly associated with the frequency of $\mathrm{AE}$ in CRS in the preceding
3 months $[6,11]$. Interestingly, a high positive bacterial culture rate of $90.9 \%$ was detected in patients during exacerbations [21]. These findings would facilitate preventive interventions on these risk factors to reduce exacerbation frequency.

Immunologic changes that occur during exacerbation offer a potential objective measure to confirm $\mathrm{AE}$ in CRS and perhaps even to predict it. The current literatures about the immunologic changes during exacerbation were all about patients with CRSwNP and studies about the immunologic changes of CRS without nasal polyps during exacerbation were lacking. From a systemic perspective, only GM-CSF and VEGF in patients with CRSwNP during exacerbation were significantly increased in serum samples when compared with controls [14]. Previous studies had shown that local production of both VEGF and GM-CSF in nasal polyps [32-34]. It is now understood that VEGF and GM-CSF play an important role in tissue remodeling and inflammatory responses. With respect to local nasal biomarkers, EDN, MPO, IL-5, IL-6, MBP, and UA within nasal secretions were all significantly increased when compared with controls $[14,22]$. Previous studies have shown that EDN, IL-5 and MBP are involved in type 2 immune responses and eosinophilic inflammation [35]. MPO is a biomarker of the neutrophil activation and high levels of MPO represent increased neutrophilic inflammation [36]. Increased IL-6 response has been associated with onset of the viral upper respiratory tract infection in healthy individuals or virus-induced asthma exacerbations [37, 38]. High serum uric acid is an indicator of oxidative stress [39] and it has proved to be a marker of the severity of asthma exacerbations [40]. These studies thereby indirectly support the role of type 2 immune responses, neutrophilic inflammation and anti-viral activity in the pathogenesis of AE in CRSwNP. Interestingly, upregulation of these serum and nasal mucus biomarkers corresponded well with subjective patient-reported worsening of symptoms suggesting that these cytokines may indeed be a reliable measure of $\mathrm{AE}$ in CRSwNP.

Recent transcriptomic and proteomic studies exploring the pathogenesis of CRS have revealed a variety of upstream targets which appear to contribute to inflammation in CRSwNP $[41,42]$. As these biomarkers may be non-invasively sampled in a prospective and serial manner, Mueller et al. demonstrated that mucus cystatin 2 and periostin levels were capable of predicting worsening SNOT-22 scores, a proxy for AE in CRSwNP, and even the need for revision surgery among patients with CRSwNP months in advance [24].

\section{Conclusions}

AE in CRS has gained increasing attention due to its significant influence on patients' quality of life and healthcare 
costs. The definition of acute exacerbation in patients with CRS to date has been generally descriptive. Our review of the literature suggests that AE in CRS is associated with an average of a 7.83-point decline in SNOT-22 and that patients with hay fever, asthma, sinus surgery history, current long-term CRS status, high body mass index, and during winter season as risk factors are at greatest risk of $\mathrm{AE}$ in CRS. Furthermore, AE in CRSwNP appears to be associated with significant increases in serum levels of GM-CSF and VEGF, as well as multiple nasal mucus cytokines including IL-5, IL-6, and MPO. Finally, recent studies suggest that upstream mucus biomarkers of Type 2 inflammation including Cystatin and Periostin may be used to predict an impending AE in CRSwNP. More studies are needed to build a consensus of the certain definition of AE in CRS which is based on the combination of the subjective and objective parameters.

\section{Abbreviations}

CRSwNP: Chronic rhinosinusitis with nasal polyps; AE: Acute exacerbations; CRS: Chronic rhinosinusitis; SNOT-22: The 22-item Sino-Nasal Outcome Test (SNOT-22); OR: Odds ratio; PI: Percentage increase; PRISMA: Preferred Reporting Items for Systematic Reviews and Meta-Analysis; ACT: Asthma Control Test; EDN: Eosinophil-derived neurotoxin; MPO: Myeloperoxidase; MBP: Major basic protein; UA: Uric acid; CST2: Cystatin SA; CST1: Cystatin SN; PST: Periostin; MCID: Minimal clinically important difference; GMCSF: Granulocyte macrophage colony-stimulating factor; VEGF: Vascular endothelial growth factor

\section{Acknowledgements}

Not applicable.

\section{Authors' contributions}

DW analyzed the data and drafted the manuscript. BSB designed the study, read, and revised the manuscript. YW designed the study and revised the manuscript. All authors have read, edited, and approved the final manuscript.

\section{Funding}

This study was supported by the Natural Science Foundation of China (81670903), Capital Health Research and Development of Special Fund (2018-2-2065), Beijing Science and Technology Nova Program

(Z201100006820086), and Beijing Hospitals Authority Youth Programme (QML20190617).

\section{Availability of data and materials}

All data gathered for the systematic review was gathered from articles cited in the paper and listed in the reference section.

\section{Ethics approval and consent to participate}

Not applicable.

\section{Consent for publication}

Not applicable.

\section{Competing interests}

The authors declare that they have no competing interests.

Received: 18 April 2020 Accepted: 14 August 2020

Published online: 18 August 2020

\section{References}

1. Smith KA, Orlandi RR, Rudmik L. Cost of adult chronic rhinosinusitis: a systematic review. Laryngoscope. 2015;125:1547-56.

2. Chung SD, Hung SH, Lin HC, Lin CC. Health care service utilization among patients with chronic rhinosinusitis: a population-based study. Laryngoscope. 2014;124:1285-9.
3. Smith SS, Evans CT, Tan BK, Chandra RK, Smith SB, Kern RC. National burden of antibiotic use for adult rhinosinusitis. J Allergy Clin Immunol. 2013;132:1230-2.

4. Rudmik L, Smith TL, Schlosser RJ, Hwang PH, Mace JC, Soler ZM. Productivity costs in patients with refractory chronic rhinosinusitis. Laryngoscope. 2014;124:2007-12.

5. Campbell AP, Phillips KM, Hoehle LP, et al. Depression symptoms and lost productivity in chronic rhinosinusitis. Ann Allergy Asthma Immunol. 2017; 118:286-9.

6. Phillips KM, Hoehle LP, Bergmark RW, Caradonna DS, Gray ST, Sedaghat AR. Acute exacerbations mediate quality of life impairment in chronic rhinosinusitis. J Allergy Clin Immunol Pract. 2017;5:422-6.

7. Fokkens WJ, Lund VJ, Mullol J, et al. European position paper on rhinosinusitis and nasal polyps 2012. Rhinol Suppl. 2012;23:1-298.

8. Orlandi RR, Kingdom T, Hwang PH, et al. International consensus statement on allergy and rhinology: rhinosinusitis. Int Forum Allergy Rhinol. 2016;6:S22-S209.

9. Rank MA, Wollan P, Kita H, Yawn BP. Acute exacerbations of chronic rhinosinusitis occur in a distinct seasonal pattern. J Allergy Clin Immunol. 2010:126:168-9.

10. Yamasaki A, Hoehle LP, Phillips KM, et al. Association between systemic antibiotic and corticosteroid use for chronic rhinosinusitis and quality of life. Laryngoscope. 2018;128:37-42.

11. Banoub RG, Phillips KM, Hoehle LP, Caradonna DS, Gray ST, Sedaghat AR. Relationship between chronic rhinosinusitis exacerbation frequency and asthma control. Laryngoscope. 2018;128:1033-8.

12. Burns PB, Rohrich RJ, Chung KC. The levels of evidence and their role in evidence-based medicine. Plast Reconstr Surg. 2011;128:305-10.

13. Zemke AC, Nouraie SM, Moore J, et al. Clinical predictors of cystic fibrosis chronic rhinosinusitis severity. Int Forum Allergy Rhinol. 2019;9:759-65.

14. Divekar RD, Samant S, Rank MA, et al. Immunological profiling in chronic rhinosinusitis with nasal polyps reveals distinct VEGF and GM-CSF signatures during symptomatic exacerbations. Clin Exp Allergy. 2015;45:767-78.

15. Kuiper JR, Hirsch AG, Bandeen-Roche K, et al. Prevalence, severity, and risk factors for acute exacerbations of nasal and sinus symptoms by chronic rhinosinusitis status. Allergy. 2018;73:1244-53.

16. Rank MA, Hagan JB, Samant SA, Kita H. A proposed model to study immunologic changes during chronic rhinosinusitis exacerbations: data from a pilot study. Am J Rhinol Allergy. 2013;27:98-101.

17. Reh DD, Lin SY, Clipp SL, Irani L, Alberg AJ, Navas-Acien A. Secondhand tobacco smoke exposure and chronic rhinosinusitis: a population-based case-control study. Am J Rhinol Allergy. 2009;23:562-7.

18. Phillips KM, Barbarite E, Hoehle LP, Caradonna DS, Gray ST, Sedaghat AR. Clinical traits characterizing an exacerbation-prone phenotype in chronic rhinosinusitis. Otolaryngol Head Neck Surg. 2019;161(5):890. https://doi.org/ 10.1177/0194599819865474.

19. Sedaghat AR, Hoehle LP, Gray ST. Chronic rhinosinusitis control from the patient and physician perspectives. Laryngoscope Investig Otolaryngol. 2018;3:419-33.

20. Speth MM, Gaudin RA, Hoehle LP, et al. Reciprocal predictive accuracy of Sinonasal symptom severity, nasal endoscopy, and frequency of past chronic rhinosinusitis exacerbations. Otolaryngol Head Neck Surg. 2018;159:766-73.

21. Ikeda K, Yokoi H, Kusunoki T, et al. Bacteriology of recurrent exacerbation of postoperative course in chronic rhinosinusitis in relation to asthma. Auris Nasus Larynx. 2011;38:469-73.

22. Kwah JH, Somani SN, Stevens WW, et al. Clinical factors associated with acute exacerbations of chronic rhinosinusitis. J Allergy Clin Immunol. 2020; 145:1598-605.

23. Phillips KM, Hoehle LP, Caradonna DS, Gray ST, Sedaghat AR. Minimal clinically important difference for the 22-item Sinonasal outcome test in medically managed patients with chronic rhinosinusitis. Clin Otolaryngol. 2018:43:1328-34.

24. Mueller SK, Wendler O, Nocera A, et al. Escalation in mucus cystatin 2, pappalysin-a, and periostin levels over time predict need for recurrent surgery in chronic rhinosinusitis with nasal polyps. Int Forum Allergy Rhinol. 2019;9:1212-9.

25. Ninomiya T, Noguchi E, Haruna T, et al. Periostin as a novel biomarker for postoperative recurrence of chronic rhinosinitis with nasal polyps. Sci Rep. 2018:8:11450

26. Xu M, Chen D, Zhou H, Zhang W, Xu J, Chen L. The role of periostin in the occurrence and progression of eosinophilic chronic sinusitis with nasal polyps. Sci Rep. 2017;7:9479. 
27. Kato $\mathrm{Y}$, Takabayashi T, Sakashita M, et al. Expression and functional analysis of CST1 in intractable nasal polyps. Am J Respir Cell Mol Biol. 2018;59:448-57.

28. Yan B, Lou H, Wang Y, et al. Epithelium-derived cystatin SN enhances eosinophil activation and infiltration through IL-5 in patients with chronic rhinosinusitis with nasal polyps. J Allergy Clin Immunol. 2019;144:455-69.

29. Lanza DC, Kennedy DW. Adult rhinosinusitis defined. Otolaryngol Head Neck Surg. 1997;117:S1-7.

30. Ramakrishnan VR, Mace JC, Soler ZM, et al. Examination of high-antibiotic users in a multi-institutional cohort of chronic rhinosinusitis patients. Int Forum Allergy Rhinol. 2017;7:343-51.

31. Chowdhury NI, Mace JC, Bodner TE, et al. Investigating the minimal clinically important difference for SNOT-22 symptom domains in surgically managed chronic rhinosinusitis. Int Forum Allergy Rhinol. 2017;7:1149-55.

32. Coste A, Brugel L, Maitre B, et al. Inflammatory cells as well as epithelial cells in nasal polyps express vascular endothelial growth factor. Eur Respir J. 2000;15:367-72.

33. Hamilos D, Leung D, Huston D, Kamil A, Wood R, Hamid Q. GM-CSF, IL-5 and RANTES immunoreactivity and mRNA expression in chronic hyperplastic sinusitis with nasal polyposis (NP). Clin Exp Allergy. 1998;28:1145-52.

34. Allen JS, Eisma R, Leonard G, Kreutzer D. Interleukin-3, interleukin-5, and granulocyte-macrophage colony-stimulating factor expression in nasal polyps. Am J Otolaryngol. 1997;18:239-46.

35. Kandikattu HK, Venkateshaiah SU, Mishra A. Synergy of interleukin (IL)-5 and IL-18 in eosinophil mediated pathogenesis of allergic diseases. Cytokine Growth Factor Rev. 2019;47:83-98.

36. Kolaczkowska E, Kubes P. Neutrophil recruitment and function in health and inflammation. Nat Rev Immunol. 2013;13:159-75.

37. Zhu Z, Tang W, Ray A. Etal. Rhinovirus stimulation of interleukin-6 in vivo and in vitro. Evidence for nuclear factor kappa B-dependent transcriptional activation. J Clin Invest. 1996;97:421-30.

38. Jackson DJ, Johnston SL. The role of viruses in acute exacerbations of asthma. J Allergy Clin Immunol. 2010;125:1178-87.

39. Muraoka S, Miura T. Inhibition by uric acid of free radicals that damage biological molecules. Pharmacol Toxicol. 2003;93:284-9.

40. Abdulnaby NK, Sayed AO, Shalaby NM. Predictive value of serum uric acid in hospitalized adolescents and adults with acute asthma. Ther Clin Risk Manag. 2016;12:1701-8.

41. Mueller SK, Nocera AL, Dillon ST, et al. Noninvasive exosomal proteomic biosignatures, including cystatin SN, peroxiredoxin-5, and glycoprotein VI, accurately predict chronic rhinosinusitis with nasal polyps. Int Forum Allergy Rhinol. 2019;9:177-86.

42. Workman AD, Nocera AL, Mueller SK, Otu HH, Libermann TA, Bleier BS, Translating transcription: proteomics in chronic rhinosinusitis with nasal polyps reveals significant discordance with messenger RNA expression. Int Forum Allergy Rhinol. 2019;9:776-86.

\section{Publisher's Note}

Springer Nature remains neutral with regard to jurisdictional claims in published maps and institutional affiliations.

Ready to submit your research? Choose BMC and benefit from:

- fast, convenient online submission

- thorough peer review by experienced researchers in your field

- rapid publication on acceptance

- support for research data, including large and complex data types

- gold Open Access which fosters wider collaboration and increased citations

- maximum visibility for your research: over $100 \mathrm{M}$ website views per year

At $\mathrm{BMC}$, research is always in progress.

Learn more biomedcentral.com/submissions 